\title{
Procedure for the elaboration of institutional policies on University social responsibility
}

\section{Procedimiento para la elaboración de políticas institucionales de responsabilidad social Universitaria}

\author{
PÉREZ-BRAVO, Julia*† \\ Universidad Autónoma de Querétaro, Cerro de las Campanas S/N, Centro Universitario, Querétaro, Qro. C.P. 76010.
}

ID $1^{\text {st }}$ Autor: Julia, Pérez-Bravo / ORC ID: 0000-0002-1310-0145, Researcher ID Thomson: N-3319-2018, CVU CONACYT ID: 501992

DOI: $10.35429 /$ EJROP.2021.12.7.31.39

Received April 18, 2021; Accepted June 30, 2021

\begin{abstract}
It is essential to make knowledge explicit in a clear way so that it can last and be passed on for the benefit of future generations. In reference to the establishment of institutional policies on University Social Responsibility (USR) in the institution under study, there are still areas of opportunity, which is why the objective of this work was established as a clear procedure for creating institutional public policies on USR, which will serve to detect needs and propose appropriate policies that will influence or contribute to the development of the various dimensions of USR in the institution. A mixed type of research was used, gathering information from various bibliographical sources and from teachers from different faculties that allowed to validate that the proposed procedure is correct, the approach was qualitative, and observation and dialectics were used as a research technique. The study was carried out by proposing the procedure derived from documentary research, own experience and discussion with teachers who participated in the exercise of drawing up proposals for institutional public policies using the procedure in question to corroborate its effectiveness. The main result of the work was to establish the procedure for the development of institutional policies on USR with their respective techniques and instruments, which will help to develop institutional policies and contribute to the implementation of USR in the institution under study, and in the medium term, to obtain distinctions from national and international organizations in this area.
\end{abstract}

Procedure, Institutional policies, University social responsibility

\section{Resumen}

Resulta imprescindible explicitar el conocimiento de una manera clara a efecto de que perdure y se pueda transmitir en beneficio de generaciones futuras. En referencia al establecimiento de políticas institucionales en materia de Responsabilidad Social Universitaria (RSU) en la institución en estudio, prevalecen áreas de oportunidad, por lo que se estableció como objetivo del presente trabajo el exponer un procedimiento claro para crear políticas públicas institucionales en materia de RSU, mismo que servirá para la detección de necesidades y plantear las políticas convenientes lo cual permitirá incidir o contribuir en el desarrollo de las diversas dimensiones de la RSU en la institución. Se usó el tipo de investigación mixto, recabando información de diversas fuentes bibliográficas y de los docentes de diversas facultades que permitieron validar que el procedimiento propuesto es correcto, el enfoque fue cualitativo y se utilizaron la observación y la dialéctica como técnica de investigación. El estudio se llevó a cabo planteando el procedimiento derivado de investigación documental, de la experiencia propia y de la discusión con docentes que participaron del ejercicio de elaboración de propuestas de políticas públicas institucionales utilizando el procedimiento en cuestión a efecto de corroborar su efectividad. El principal resultado del trabajo fue establecer el procedimiento para la elaboración de políticas institucionales en materia de RSU con sus respectivas técnicas e instrumentos lo cual servirá para que, se puedan desarrollar políticas institucionales y coadyuvar en la implementación de la RSU en la institución en estudio y en un mediano plazo, poder obtener distinciones de organismos nacionales e internacionales en esa materia.

Procedimiento, Políticas institucionales, Responsabilidad social universitaria

Citation: PÉREZ-BRAVO, Julia. Procedure for the elaboration of institutional policies on University social responsibility. ECORFAN Journal-Republic of Paraguay. 2021. 7-12: 31-39

$\dagger$ Researcher contributing as first author. 


\section{Introduction}

The constant search to improve the quality of education in Higher Education Institutions (HEIs) has led them to prepare policies, strategies, procedures, programs, norms and actions and, in general, all kinds of plans necessary for them to function within the framework of national and international requirements regarding the HEIs themselves, also giving due importance to the trends and innovations that have an impact on social development; Thus, it becomes necessary to make explicit the knowledge to prepare these plans, according to the real needs, i.e. the deficiencies needed to be solved within the institution, including the procedures.

The focus on the impacts of organizational management, education, research and social participation, centered on the stakeholders of educational institutions (students, authorities, teaching and non-teaching staff and researchers, suppliers, employers, competitors, society in general, government and the environment), is known as university social responsibility (USR) and has given rise to a great deal of research on this topic; This is how we find authorities on the subject such as Francois Vallaeys in Latin America, who has carried out work ranging from a manual of first steps, proposals for models, definitions of the topic analyzed in depth, specific areas for the diagnosis of responsible behavior with its indicators, research instruments to diagnose USR, among others.

Vallaeys, regarding the need to generate adequate instruments for the establishment of institutional public policies, has commented that it is necessary to initiate the production of tools or instruments for the management of USR, which (among other benefits) should allow the participation of institutional stakeholders in the management and elaboration of improvement strategies in the HEI, Vallaeys (2006), however, it is difficult to find research that exemplifies the elaboration of institutional public policies on USR in each of its phases, including the needed instruments. Regarding public policies, Velásquez-Gavilanes (2009), stated that it is the integrating process of decisions, actions and inactions, agreements and instruments, conceived from the collective to the authorities, with the aim of solving or preventing a situation defined as collective.
The institutional philosophy under study, such as the Statutes, the University Educational Model (MEU) and the Institutional Mentoring Program (PIT), includes general policies on USR and consultations have been carried out among stakeholders for their elaboration, however, these are still very general and are not detailed for each different level, specific areas such as faculties, departments, laboratories, etc., although it is worth mentioning that there are some documents such as codes of ethics, specific plans for some faculties and norms among other documents, are yet to be solved in order to improve both the management in the four impact axes of the RSU and the conditions of the interested parties in the institution, a situation that if solved can generate the needed conditions to obtain a distinction as a socially responsible institution at national level granted by various institutions such as the Mexican Centre for Philanthropy (CEMEFI).

Now, although there are general policies on USR, the question is: How can institutional policies on USR be created in detail, what is the appropriate procedure for them to be created in a more user-friendly way and how can this have an impact on the institution under study in order to obtain a distinction in the medium term?

From this observation, which serves to generate the research question, a problem also arises: institutional policies exist in general, but in particular they are still in an incipient stage, the cause of which may be the lack of clear procedures and detailed instruments for their creation.

Thus, the objective of this work is to set out a procedure for creating institutional policies on USR, which will serve to detect needs and propose appropriate policies, which will influence or contribute to the development of the various dimensions of USR in the institution under study and in the medium term will contribute to obtaining a distinction in this area. To achieve the above, the proposal of procedures to create institutional policies on USR was developed from the documentary review and own experience, as well as participated in the delivery of the course on the same topic in various faculties of the institution where it was possible to observe the effectiveness of the instruments with the participation of teachers to develop their policy proposals using the same during the years 2019, 2020 and 2021 . 
The methodology used for this research was that of a mixed type, with field research predominating, given that, although a theoretical overview of the main variables was carried out, most of the research was obtained from direct contact in the field with the participants in the USR course and in the institutional policy proposal exercise. The sample consisted of 270 teachers out of a total of 2446 , i.e. $11.03 \%$.

It can also be said that it was a case study since it was considered for this study only and specifically to a higher education institution, dialectics was also used to know the pros and cons of these instruments.

\section{Theoretical context}

\subsection{Public Policy}

In Mexico, public policies are conceived as "the product of the state's decision-making processes in the face of certain public problems; these decision-making processes involve actions or omissions by government institutions" (Cámara de Diputados 2021). In this sense, this definition is in line with the proposal made by Dye quoted by Quiñones (2019) "Public policy is what the government chooses to do or not to do". This position is imposed and capitalized by the government body or in the case of the private sector, a decision of the employer, which implies making decisions in the name of the common good, however, many of these decisions could be subjective, as they depend on the perception of those who lead without considering the opinion of society itself. The above proposals are far from the original idea established by Lasswell in 1951 cited by Ortegón-Quiñones (2019), where he states that "public policies should concentrate on the study or analysis of public problems.

According to Velásquez-Gavilanes (2009), a public policy is the integrating process of decisions, actions and inactions, agreements and instruments, conceived from the collective towards the authorities, with the aim of solving or preventing a situation defined as collective. According to IDB (2006) "public policy conceptions are the result of complex exchanges between political actors over time", so they change, adapting to the situations of each country and time, however, both seek to reach a consensus on conflicts by establishing incentives for collective action, providing goods and services.
Actions that have an implicit moral duty, the ethics of rights and obligations, values that do not violate the right and freedom of individuals to choose their own collective and individual objectives and not those imposed. In this sense, the participation of each of the social actors must be incorporated to give public policies the capacity for self-management to reconcile conflicts through fair and effective regulations Díaz-Aldret (2017) and OrtegónQuiñones (2019).

To ensure the integrity of the being of public policies, they must have elements that legitimize them, in this sense, the proposal of Méndez-Martínez (1993) is inherent to the process of integrating decisions and considers the collective:

a. Detection of the problem. Identified by the collective, it is the inherent reference point of the policy.

b. Diagnosis. The causes are identified, and some measures are proposed to control or mitigate the problem.

c. Solution. The objectives to solve the problem are determined.

d. Strategy. This is the set of actions to solve the problem

e. Resources. The tools that the actions of the strategy will be carried out with.

f. Execution. The implementation of the strategies.

\subsection{University social responsibility}

According to Montalvo, Villanueva, Armenteros and Cervantes (2016), in Mexico, following the actions of the Mexican Centre for Philanthropy (CEMEFI) and the principles of the Global Compact on corporate social responsibility, universities, according to their priority areas, define their own model or structure of USR to integrate it with institutional objectives, following the use of the Manual of Vallaeys, De la Cruz, and Sasia (2009) disseminated by the International Development Bank (IDB) and Mexican Association of USR.

And although social responsibility is currently a well-known topic, mainly in the business world, research on the subject applied in the educational world is relatively new and is still in progress and increasing by leaps and bounds in Latin America and Mexico, as shown by the efforts made by: 
(Among other governmental and nongovernmental organizations), the Union of Latin American University Social Responsibility (URSULA), which brings together different development actors to discuss in depth the role of the university and the different strategies and methodologies to carry it out effectively.

The above can also be observed by finding that research on university social responsibility has increased by $500 \%$, according to Baca (2015), who cites Gordon \& Gelardi (20059 and De la Cuesta \& Sánchez, (2011), among other authors, and mentions in this regard, that universities have become a focus of interest in this area and are a fruitful field of research.

University Social Responsibility (USR) has been defined as "a new university management policy that is being developed in Latin America to respond to the organizational and academic impacts of the university. It differs from both traditional solidarity outreach and a mere declarative unilateral commitment and forces each university to question its epistemic assumptions and its hidden curriculum. As such, USR is not comfortable, as it forces institutional self-criticism" (Vallaeys, François, 2014).

Vallaeys, François (2009), the most recognized authority on the subject in Latin America for his work on social responsibility, establishes the following areas or impacts, dimensions and axes for USR:

Four spheres of action or impact of the university

Organizational sphere: as an institution that operates around a university project, with a structure that develops it and specific policies that promote it. It is also an institution that consumes, hires, generates waste, and so on.

1. Educational sphere: as an institution that is responsible for the education of its students, with a professional and civic vocation.

2. Knowledge sphere: as an institution that researches, produces knowledge and transmits it.

3. Social sphere: as an institution that forms part of society and interacts with other agents, collectives and communities, both locally and globally.
It also establishes the following as stakeholders, interested parties or groups of interest: Non-teaching staff, teaching and research staff, authorities, students, suppliers, alumni, employers, competitors, local communities, partner organizations and the state. As well as the four axes of involvement of the same RSU, which are also considered as the duty to do of a higher education institution at the higher level

1. Responsible campus: implies the socially responsible management of the organization and its institutional procedures, the working environment, the management of human resources, internal democratic processes and care for the environment.

2. Professional and citizenship training: socially responsible management of academic training (in its subject matter, curricular organization, methodology and didactic proposal).

3. Social management of knowledge: socially responsible management of the production and dissemination of knowledge, research and epistemological models promoted from the classroom. In other words, guiding scientific activity, coordinating lines and research with external stakeholders so that knowledge is produced in accordance with the local and national development agenda and public sector social programs.

4. Social participation: this is the socially responsible management of the university's participation in the community. That is, carrying out projects with other actors creating links for mutual learning and social development.

\section{Development and results}

The procedure for the elaboration of institutional public policies is developed after consulting bibliographical material, prior to the teaching of a course on university social responsibility to teachers in the educational institution under study; as a section of the aforementioned course, the practice of formulating these policies is developed, in which the procedure is used with its respective techniques and instruments. 
With the institutional public policies derived from the practice, a dialogue is held with the teachers on the results obtained and the practicality and feasibility of using them in their faculty and on the feasibility of deriving positive results, and institutional public policies have always been derived from real needs and it has been observed, discussed, and concluded that the procedure with its techniques and instruments is effective. This workshop has been given for three consecutive years an average of three times each in and for different faculties, starting in person and currently virtually, a situation that has allowed us to verify the validity and reliability of the established procedure, since this procedure has been used by 20 teachers out of a total of 2446 , i.e. $11.03 \%$.

Some of the activities proposed in the "Roadmap for Corporate Social Responsibility CSR in the River Region 2015 of Vision Valdivia, International Labour Office (ILO) and the European Union (EU) are also considered for the development of institutional public policies on CSR, where they are specified as phases for developing CSR policies, specifically as lines of action and projects to detect areas of opportunity or needs that are described as "gaps" in that document. It also considers the "organization for action", which establishes committees, commissions and other bodies that need to be formed to implement the proposed policies.

Following the review of various bibliographical sources, the procedure for the development of institutional public policies for educational institutions in the field of USR is proposed with a logical sequence, but it can be developed in a flexible way according to the needs and characteristics of the institution.

Procedure:

1. Detection of actions carried out and pending in the field of USR.

2. Prioritization of needs

3. Find the root causes of the detected needs, i.e. the problems that have not been solved.

4. Prioritize unresolved problems

5. Proposing possible alternatives to solve the unresolved problems.

6. Substantiating the alternatives

7. Projecting policy or project objectives, suggesting the necessary organization for the implementation of the policy or project.
8. Establishment of participants and leaders of the bodies necessary for the implementation, operation, analysis, evaluation and correction of the policies or projects.

What is relevant here is the design of the formats or instruments for the elaboration of the policies, which can be found in the annexes of this document. However, the procedure is shown in this section in a flow chart.

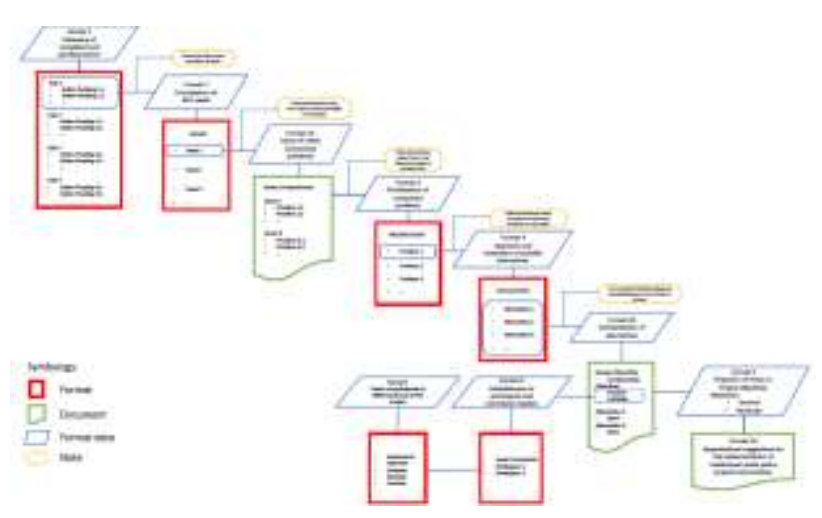

Figure 1 Flowchart for the elaboration of institutional MSW policies

Source: Own Elaboration as follows:

The formats or instruments designed are

Format 1. Detection of completed and pending actions.

Format 2. Hierarchization of MSW needs

Format 2A. Causal of needs

Format 3. Prioritization of unresolved problems

Form 4. Identification and evaluation of possible alternatives

Format 4A. Rationale for alternatives

Format 5. Projection of policy or project objectives

Format 5A. Organizational suggestions for policy or project implementation

Format 6. Establishment of participants and commission leaders

Format 7. Choice of participants in different phases of policy or project elaboration. 


\section{Conclusions}

In the present work, emphasis was placed on the need to have institutional public policies on USR, that they exist in general, guiding documents in the institution under study, that there are also actions in the field of University Social Responsibility but that there are still areas of opportunity, for which it is necessary to have the appropriate procedures that serve as a guide for those interested in developing proposals in this area for their faculties or areas of work or in general for the educational institution.

Taking as a basis that being socially responsible means being aware of the impacts generated by the actions of each and every one of the stakeholders, reducing those that are negative or harmful, and that in the courses given on the topic, the participants were interested in having their proposals for institutional public policies taken into account, as they considered USR a priority for those who strive to improve their performance with social responsibility; it follows that friendly instruments or guides should be provided to those interested in elaborating proposals so that they can raise them, regardless of their area of knowledge or experience.

Therefore, the procedure and instruments presented in this document are considered an important contribution to the development of institutional public policies on university social responsibility, being the main recipients those responsible for guiding the formulation and implementation of policies and strategies in this area but benefiting a larger group that make up the stakeholders of the educational institution under study.

\section{References}

Baca Neglia, Hilda Zoraida (2015) La responsabilidad social universitaria: propuesta conceptual y medición en el ámbito de una universidad privada de lima - perú 2015

Banco Interamericano de Desarrollo (BID) (2006). La política de las políticas públicas. Progreso económico y social en América Latina. Informe 2006, Washington, BID, http://www.iadb.org/res/ipes/2006/index.cfm?L anguage $=$ Spanish .
Cámara de Diputados (2021). Cámara de Diputados. Servicio de Investigación y Análisis. De la Cuesta, M. (2011). Responsabilidad Social Universitaria. Madrid: Fundación Carolina.

Díaz-Aldret, A. (2017). Participación ciudadana en la gestión y en las políticas públicas. Gestión y política pública, 26(2), 341379.

Gordon, I., \& Gelardi, M. (2005). Factors That Affect Understanding of Social Responsibility Accounting. Canadian Accounting Perspectives, 4(1), 31-59.

Méndez-Martínez, José Luis (1993). La política pública como variable dependiente: hacia un análisis más integral de las políticas públicas. Revista Foro Internacional, v. 33, no. 1 (131) (ene.-mar. 1993) Visión Valdivia, Oficina Internacional del Trabajo y Organización de las Naciones Unidas (2015), Hoja de Ruta para la Responsabilidad Social Empresarial RSE en la region de los ríos, Un aporte al Plan de Responsabilidad Social de Chile desde los empresarios de la Región de los Ríos.

Montalvo Morales Jesús Alberto, Villanueva Armenteros Yanet, Armenteros Acosta Maria del Carmen y Cervantes Ávila Yazmín Guadalupe (2016), la responsabilidad social universitaria: autodiagnóstico de la efectividad de la relacion universidad sociedad en la universidad estatal de coahuila, méxico, recuperado

de: http://www.aeca1.org/pub/on_line/comunicacio nes_xviiicongresoaeca/cd/158c.pdf

Observatorio de la RSC (2005) Guía de la RSC para las Pymes. Disponible en: http://observatoriorsc.org/wp-

content/uploads/2013/07/Guia_RSC_PYME.pd $\mathrm{f}$

Ortegón-Quiñones, E. (2019). Políticas públicas: métodos conceptuales y métodos de evaluación. Universidad Continental, Fondo Editorial.

Pacto mundial o global compact a través de: https://www.unglobalcompact.org/ 
Unión de Responsabilidad Social Universitaria Latinoamericana [URSULA] (2018). Investigación Continental URSULA: estado del arte de la Responsabilidad Social Universitaria (RSU) en América Latina - 2018. Recuperado de: $\quad \mathrm{http}: / /$ unionursula.org/investigacioncontinental-rsu2018/

Vallaeys, François. (2014). La responsabilidad social universitaria: un nuevo modelo universitario contra la mercantilización. Revista iberoamericana de educación superior, 5(12), 105-117. Recuperado en 21 de enero de 2019, de http://www.scielo.org.mx/scielo.php?script=sci _arttext\&pid=S2007-

$28722014000100006 \& \operatorname{lng}=\mathrm{es} \&$ tlng=es.

Vallaeys, François, De la Cruz Cristina y Sasia Pedro M. (2009), Responsabilidad social universitaria: manual de primeros pasos, McGraw-Hill interamericana editores, s.a. de c.v., Derechos reservados (C) Banco Interamericano de Desarrollo, 2009. www.iadb.org

Velásquez-Gavilanes, R. (2009). Hacia una nueva definición del concepto "política pública" Desafíos, 20: 149-187

\section{Appendix 1}

Format 1: Identification of completed and pending actions on MSW in your area of work

\begin{tabular}{|c|c|c|c|c|c|}
\hline Axes & Impact & Management in & $\begin{array}{l}\text { Actions } \\
\text { carried out }\end{array}$ & Evidences & $\begin{array}{l}\text { Pending } \\
\text { actions }\end{array}$ \\
\hline $\begin{array}{l}\text { Campus } \\
\text { Responsable }\end{array}$ & \begin{tabular}{|l|} 
Organisation \\
(Authorities, teaching \\
and non-teaching \\
staff, suppliers)
\end{tabular} & $\begin{array}{l}\text { Procedures } \\
-\quad \text { Work climate } \\
\text { HR management } \\
\text { Democratic } \\
\text { processes } \\
\text { Environment }\end{array}$ & & & \\
\hline $\begin{array}{l}\text { Professional } \\
\text { Traaning } \\
\text { Citizenship }\end{array}$ & \begin{tabular}{|l|} 
Education \\
(Students)
\end{tabular} & $\begin{array}{l}\text { Academic training } \\
\text { - Vocational training }\end{array}$ & & & \\
\hline $\begin{array}{l}\text { Social } \\
\text { Management of } \\
\text { Knowledge }\end{array}$ & \begin{tabular}{|l|}
$\begin{array}{l}\text { Knowledge } \\
\text { (Teachers } \\
\text { researchers) - }\end{array}$ \\
\end{tabular} & $\begin{array}{l}- \text { Knowledge } \\
\text { production } \\
\text { management } \\
- \text { Research } \\
- \text { Epistemological } \\
\text { models }\end{array}$ & & & \\
\hline $\begin{array}{l}\text { Social } \\
\text { Participation of } \\
\text { Knowledge }\end{array}$ & \begin{tabular}{|l|} 
Participation \\
(Civil society \\
Private sector \\
Public sector, etc.)
\end{tabular} & $\begin{array}{l}\text { - Community } \\
\text { participation } \\
\text { - (linkage) }\end{array}$ & & & \\
\hline
\end{tabular}

Source: Own Elaboration

\section{Appendix 2}

Format 2 Ranking of unmet needs (pending actions) in terms of MSW in UAQ Evaluate from 1 to 3,1 being the least serious or urgent and 3 the most serious or urgent

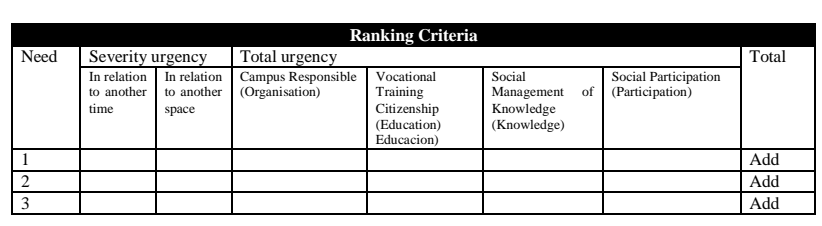

Source: Own Elaboration

Format 2A Description of the needs identified according to their hierarchical ranking. (Add as many as necessary to describe all the needs).

\section{Name of the identified need: Name}

\section{Rationale of the identified need}

The main cause of this need is "describe the cause".

Which makes the following unresolved problems prevalent:

Problem 1: Describe Problem 1

Problem 2: Describe Problem 2

\section{Appendix 3}

Format 3 Prioritization of unresolved problems (Add as many as necessary to cover all causes.)

\section{Name of identified need: Name \\ Cause of identified need: Name}

Assign a score from 1 to 3 depending on the degree of urgency in the area of concern, 1 being the least serious or urgent and 3 the most serious or urgent.

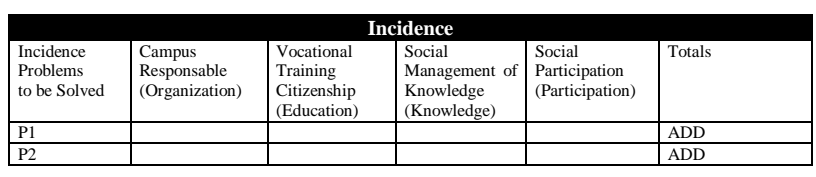

Source: Own Elaboration

PÉREZ-BRAVO, Julia. Procedure for the elaboration of institutional policies on University social responsibility. ECORFAN JournalRepublic of Paraguay. 2021 


\section{Appendix 4}

Format 4 Evaluation of possible alternatives (Add as many as necessary to cover each problem).

Name of the identified need: Name

Cause of the identified need: Name

Problem to be solved: Name

Assign a score from 1 to 3 depending on the possibilities of intervention, effectiveness, and political feasibility, 1 being the least possibilities and 3 being the most possibilities.

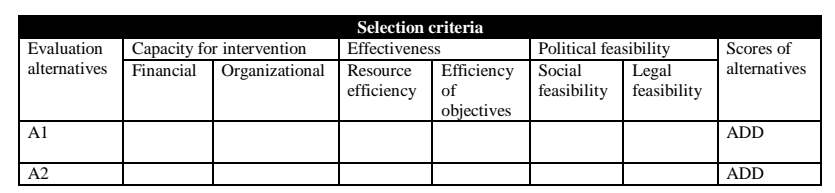

Source: Own Elaboration

Format 4A Analysis of the selected alternatives for problem solving

Name of the identified need: Name

Cause of the identified need: Name

Problem to be solved: Name

Alternative: name

Substantiate

\section{Objectives of the alternative \\ Overall objective \\ Describe}

\section{Specific objectives}

Describe

\section{Projects for the selected alternative}

1. Institutional project: Name

2. Institutional project: Name

Institutional project activities "Name"

\section{Appendix 5}

Format 5 Projection of objectives

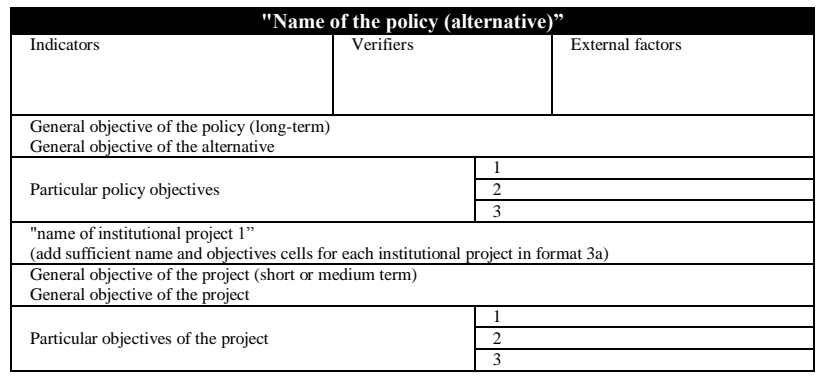

Source: Own Elaboration

Format 5A Organization for the implementation of the public policy projects and their activities (Fill in the whole format and fill in the table)

For the implementation of institutional project activities to carry out the proposed public policy, the following commissions and committees will be formed:

- Commission...

- Committee...

- Committee...

- Commission...

- Committee...

- Committee...

- Committee...

- Committee...

- Committee...

\section{Appendix 6}

Format 6 Establishment of participants and committee leaders

During their exercise, the commissions may discuss and decide to form sub-committees for particular exercises not covered by the initial policy.

The commissions shall be composed as follows:

\begin{tabular}{|l|l|l|}
\hline Thematic commission & Leads & Participants \\
\hline Commission of... & & \\
\hline Commission of... & & \\
\hline Commission of... & & \\
\hline
\end{tabular}

Source: Own Elaboration 


\section{Appendix 7}

Format 7 Election of participants in different phases of the project

Implementation, Operation, Analysis, Evaluation and Correction of Institutional Projects

(Fill in the table)

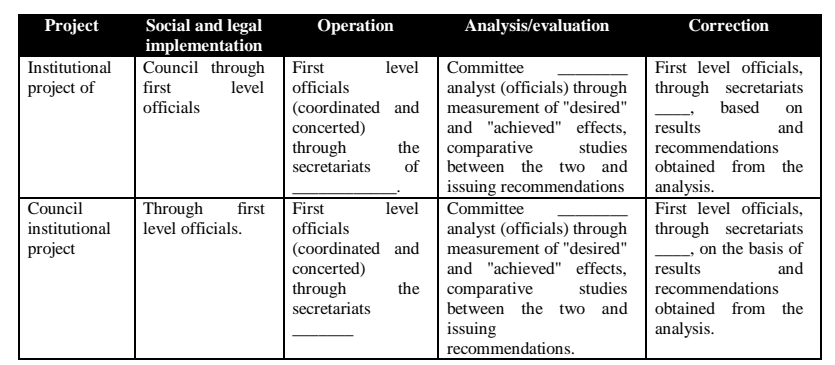

Source: Own Elaboration 